\title{
MANFAAT STIMULUS OTOT-OTOT PAYUDARA (BREAST MASSAGE) DAN PENGELUARAN OKSITOSIN (PIJAT OKSITOSIN) TERHADAP VOLUME KOLOSTRUM PADA IBU POSTPARTUM
}

\author{
BREAST MASSAGE AND EXPOSURE OF OXYTOCOSINE TO VOLUME \\ COLOSTRUM IN POSTPARTUM MOTHER
}

\author{
Naomi Parmila ${ }^{1}$,Tuti Yulianingsih ${ }^{2}$ ) \\ 1)2) Program Studi Diploma III Kebidanan \\ Akademi Kebidanan Graha Mandiri Cilacap \\ Email : Naomiparmila@gmail.com
}

\begin{abstract}
ABSTRAK
Tidak memberikan ASI pada bayinya dapat mengganggu pemenuhan kebutuhan nutrisi bayi. Selain itu, juga karena kurangnya pengetahuan ibu tentang cara-cara untuk meningkatkan volume kolostrum dan produksi ASI yang dalam hal ini yaitu mengenai stimulus otot-otot payudara dan pengeluaran oktosin. Diare erat kaitannya dengan perilaku sehat, ketersediaan air bersih, serta sanitas dasar. Pneumonia terkaid eratdengan indioor and outdoorpollution (populasi didalam dan diruangan), ventilasi, kepadatan hunian, jenis bahan bakar yang dipakai, kebiasaan merokok, status gizi, ststus imunisasi dan lam pemberian ASI. Populasi dalam penelitian ini ibu pos partum yang terdaapat pada RSUD Hj. Anna Lasmanah Banjarnegara.penelitian ini menggunakan teknik sampel incidental. Berdasarkan data penelitian yang diperoleh di RSUD hj. Anna Lasmanah Banjarnegara menunjukkan bahwa tindakan Stimulasi otot-otot payudara (brast massage) dan pengeluaran oksitosin (pijat oksitosin (pijat oksitosin) berpengaruh terhadap kolostrum. Manfaat dari breast massage adlah melancarkan reflex let down, meningkatkan volume ASI dan encegah payudara bengkak. Terdapat manfaat yang bermakna antara stimulasi-stimulasi otot-otot payudara (brast massage) dan pengeluaran oksitosin (pijat okstosin) terhadap volume kolostrum pada ibu post partum.
\end{abstract}

Kata Kunci : Breast Massage, Oksitosin, Postpartum

\section{ABSTRACT}

Not providing breastfeeding on her babycan interfere with the fulfillment of the needs of the infant nutrition. In addition, also because of the mother's lack of knowledge about ways to increase the volume of colostrum and breastfeeding production which in this case regarding breast muscles stimulus and spending oktosin. Closely related to diarrhea in healthy behaviour, the availability of clean water, as well as basic sanitas. Pneumonia terkaid eratdengan indioor and outdoorpollution (population ins ide and diruangan), ventilation, residential density, the type offuel used, the smoking habits, nutritional status, immunization and ststus lam breast. The benefits of breast massage was waged the let down reflex, increase the volume of breast milk and breast swelling encegah. There are meaningful benefitsbetween stimulationstimulating breast muscles (brast massage) and expenditure of oxytocin (a massage okstosin) against the volume of colostrum in the mother postpartum.

Keywords: Breast Massage, Oxytocin, Peurperium 


\section{PENDAHULUAN}

Kolostrum merupakan komposisi ASI paling sesuai untuk pertumbuhan bayi dan juga mengandung zat pelindung. Kolostrum merupakan cairan kental dengan warna kekuning-kuningan yang lebih banyak mengandung protein, antibody, mineral dibanding dengan ASI matur dan merupakan pencahar yang yang membersihkan mekonium sehingga mukosaa usus bayi baru lahir segera bersih (Anggraeni, 2010). Tidak memberikan ASI pada bayinya dapat mengganggu pemenuhan kebutuhan nutrisi bayi. Selain itu, juga karena kurangnya pengetahuan $\mathrm{ibu}$ tentang cara-cara untuk meningkatkan volume kolostrum dan produksi ASI yang dalam hal ini yaitu mengenai stimulus otot-otot payudara dan pengeluaran oktosin. Salah satu penyebab kematian bayi dan terutama kematian balita adlah penyakit infeksi diare dan peneumonia. Pencegahan deteksi dini, serta penanganan yang cepat dan tepat dapat menekan kematian yang diakiatkan penyakit ini.

\section{METODE PENELITIAN}

Populasi dalam penelitian ini ibu pos partum yang terdaapat pada RSUD $\mathrm{Hj}$. Anna Lasmanah Banjarnegara.penelitian ini menggunakan teknik sampel incidental yaitu teknik penentuan sampel berdasarkan kebetulan, siapa saja ayng secara kebetulan bertemu dengan peneliti dapat digunakan sebagai smapel bila dipandang orang yang kebetulan ditrmui itu cocok sebagai sumber data. Berdasarkan tektik sampling tersebut sampel dalam penelitian ini adalah populasi ibiu post partum yang terdapat pada RSUD $\mathrm{Hj}$. Anna Lasmanah Banjarnegara.
Metode penelitian ini menggunakan metode analitik observasi looperatif dimanan peneliti mengobservasikan jumlah pengeluaran kolostrum sebelum dan sesudah dilakukan stimulasi otot-otot payudara (breast massase) dan pengeluaran oksitosin (pijat oksitosin). Teknik analisa data digunakan untuk menganlisa rumusan masalah hipotesis dalam penelitian ini adalah menggunakan rumus "T-Test Realated", karena penelitian ini untuk mengji hiootesis komperatif dengan jenis yaitu rasio.

\section{HASIL DAN PEMBAHASAN}

Populasi dalam penelitian ini ibu pos partum yang terdapat pada RSUD $\mathrm{Hj}$. Anna Lasmanah Banjarnegara. Sampel dalam penelitian ini sebanyak 66 responden. Teknik sampel yang digunakan adalah sampel incidental yang artinya teknik penentuan sampel berdasarkan kebetulan, siapa saja yang secara kebetulan bertemu dengan peneliti dapat digunakan sebagai sampel bila dipandang orang yang kebetulan ditemui itu cocok sebagai sumber data. Berdasarkan tehnik sampling tersebut sampel dalam penelitian ini adalah populasi ibu post partum yang terdapat pada RSUD $\mathrm{Hj}$. Anna Lasmanah Banjarnegara.

Metode penelitian eksperimental ini menggunakan metode analitik observasi kooperatif dimana peneliti mengobservasi jumlah pengeluaran kolostrum sebelum dan sesudah dilakukan perlakuan berupa stimulasi otot-otot payudara (breast massage) dan pengeluaran oksitosin (pijat oksitosin). Teknik analisa data digunakan untuk menganlisa rumusan masalah. Hipotesis dalam penelitian ini adalah menggunakan rumus " $T$ Test Realated", karena penelitian ini 
untuk menguji hipotesis komparatif dengan jenis yaitu rasio.

Hasil Univariat karakteristik penelitian adalah sebagai berikut:

Tabel 1. Distribusi Frekuensi

Karakteristik Responden

\begin{tabular}{|c|c|c|c|c|}
\hline $\begin{array}{c}\text { Karakteris } \\
\text { tik }\end{array}$ & & Kriteria & $\mathrm{N}$ & $\%$ \\
\hline \multirow[t]{3}{*}{ Umur } & $\mathrm{a}$ & $<20$ & 0 & 0 \\
\hline & $\mathrm{b}$ & $20-35$ & 47 & 71.21 \\
\hline & c & $>35$ & 19 & 28.79 \\
\hline \multicolumn{3}{|c|}{ Jumlah } & 66 & 100 \\
\hline \multirow[t]{3}{*}{ Paritas } & $\mathrm{a}$ & Primigravida & 18 & 27.28 \\
\hline & $\mathrm{b}$ & Multigravida & 48 & 72.72 \\
\hline & Jum & & 66 & 100 \\
\hline
\end{tabular}

Sumber: Data Olahan Sendiri (2016).
Berdasarkan tabel 1 menunjukan bahwa sebagian besar ibu berusia 2035 tahun yaitu sebanyak 47 orang (71.21\%), diikuti ibu dengan kelompok umur $>35$ tahun yaitu sebanyak 19 orang $(28.79 \%)$ dan tidak ada dengan usia $<20$ tahun

Berdasarkan karakteristik paritas, yakni primigravida, multigravida. Dan sebagian besar sampel berupa multigravida yaitu 48 orang (72.72 $\%$ ), diikuti ibu bersalin primigravida sebanyak 18 orang ( $27.28 \%)$.

Hasil penolahan uji statistic T Test Related tergambar oleh tabel 2 berikut ini:

\begin{tabular}{|c|c|c|c|c|c|c|c|}
\hline \multicolumn{8}{|c|}{ Hasil Olahan Paired Differences } \\
\hline \multirow[t]{2}{*}{ Mean } & \multirow{2}{*}{$\begin{array}{c}\text { Std } \\
\text { Deviation }\end{array}$} & \multirow{2}{*}{$\begin{array}{c}\text { Std. } \\
\text { Error } \\
\text { Mean }\end{array}$} & \multicolumn{2}{|c|}{$\begin{array}{l}95 \% \text { Confidence Interval of } \\
\text { the Difference }\end{array}$} & \multirow[t]{2}{*}{$\mathrm{T}$} & \multirow[t]{2}{*}{$\mathrm{df}$} & \multirow{2}{*}{$\begin{array}{l}\text { Sig (2- } \\
\text { tailed) }\end{array}$} \\
\hline & & & Lower & Upper & & & \\
\hline-0.13 & 0.267 & 0.03 & -0.19 & -0.07 & -4.001 & 65 & 0.001 \\
\hline
\end{tabular}

Sumber: Data Olahan Sendiri (2016).

Berdasarkan hasil analisis data pada tabel 2 didapatkan nilai thitung sebesar 4.001 untuk payudara kanan dan $t_{\text {hitung }} 5.255$ untuk payudara kiri. Jika $\mathrm{df}=66-1=65 \quad$ dan $\quad \alpha=0,05$ maka didapatkan $t_{\text {tabel }}$ 1.671. $t_{\text {hitung }} \leq \mathrm{t}_{\text {tabel }}$ maka Ho diterima, Ha ditolak dan jika $\mathrm{t}_{\text {hitung }} \geq \mathrm{t}$ tabel maka Ho ditolak, Ha diterima. Dalam uji hipotesis didapatkan $\mathrm{t}$ hitung $\geq \mathrm{t}$ table (4.001>1.671) dan (5.255>1.671), maka dapat disimpulkan bahwa Ho ditolak dan Ha diterima.

Hasil penelitian ini sejalan dengan hasil penelitian dari Fione Tri Wulandari dkk yang berjudul pengaruh pijat oksitosin terhadap pengeluaran kolostrum pada ibu post partum di Rumah Sakit Umum daerah provinsi kepulauan riau, hasil dari penelitian tersebut adalah Pijat oksitosin berpengaruh terhadap rerata pengeluaran kolostrum pada ibu post partum ( $p$ value $=0.006)$. Selain itu hasil penelitian dari Eko Mardiyaningsih tahun 2010 dengan judul Efektivitas Kombinasi Teknik Marmet dan Pijat Oksitosin Terhadap Produksi ASI Ibu Post Sectio Sesarea di Rumah Sakit Wilayah Jawa Tengah menyatakan bahwa metode kombinasi teknik marmet dan pijat oksitosin efektif dapat meningkatkan produksi ASI ibu post secsio sesarea.

\section{KESIMPULAN}

Berdasarkan hasil penelitian yang diperoleh dalam penelitian ini dapat disimpulkan bahwa : terdapat manfaat yang bermakna antara stimulasi-stimulasi otot-otot payudara (breast massage) dan pengeluaran oksitosin (pijat okstosin) terhadap volume kolostrum pada ibu post partum. 


\section{DAFTAR PUSTAKA}

Azwar. 2010. Metode Penelitian, Cetakan ke X. Yogjakarta: Pustaka Pelajar.

Anggraini, Yetti. 2010. Asuhan Kebidanan Masa Nifas. Yogjakarta: Pustaka Rihama.

Bahiyatun. 2009. Asuhan Kebidanan Nifas Normal. Jakarta: EGC

Brampoton. 2013. The Benefit Of Massage Therapy. Canada: Metriland Group.

Cuningham, F. Gary. 2005. Wiliams Obstetetriscs. Jakarta: EGC.

Depkes RI. 2011. Gizi KIA Dalam Materi Advokasi BBL. Jakarta: Depkes RI.

Kamus Besar Indonesia. 2005. Jakarta: Balai Pustaka.

Notoatmodjo, S. 2002. Metodelogi Penelitian Kesehatan. Jakarta: Rineka Cipta.

Roesli,U. 2004. Mengenai ASI Eksklusif. Jakarta: Trubulus Griwidja.

Slone. 2003. Anatomi dan fisiologi untuk pemula. Jakarta: EGC.

Sugiyono, 2010. Metologi Penelitian Pendekatan Kuantitatif, Kualitatif, R\&D. Bandung: Alfabeta.

Varney, Hellen dkk. 2007. Varneys Midwifery. Jakarta: EGC.

Verrals Sylvia. 2003. Anatomi dan Fisiologi Teraan dalam Kebidanan. Jakarta:EGC 